\title{
Od bojovníka k rytírí - na okraj úvah o proměně českých zemí ve vrcholném středověku ${ }^{1}$
}

From a warrior to a knight - incidental remarks on the transformation of the Czech lands in the High Middle Ages

\author{
Robert Antonín
}

\begin{abstract}
Abstrakt
Studie je zaměřena na analýzu šíření rytířské kultury ve středověkých českých zemích. Předkládá pokus o revizi stávajícího stavu bádání, v rámci kterého je výzkum rytírství metodologicky podřízen výkladovému modelu státu tzv. „středoevropského typu“. Jádro textu tvoří úvahy o procesu geneze rytířské kultury v českých zemích, jako o jednom z projevů kulturního transferu. Síření rytířství ve středověkých Čechách autor chápe jako doklad proměny myšlenkového světa nobility a její sebeidentifikace. Oproti dosavadnímu bádání představuje text hypotézu, jež posouvá přijetí rytířského kulturního kódu na počátek 12. století, a do značné míry tak v tomto aspektu stírá uměle vytvořené hranice mezi západoevropskou a středovýchodoevropskou oblastí ve středověkém období.
\end{abstract}

\begin{abstract}
The study analyses the spreading of the chivalric culture of transformation in the Czech lands of the Middle Ages. The author presents an attempt at a revision of the current state of research, within which the investigation of chivalry is methodologically subjected to the interpretive model of the so-called "Central European type of state". The core of the text is comprised by reflections on the process of the genesis of chivalric culture in the Czech lands as one of the manifestations of cultural transfer. The author understands the spreading of chivalry in Bohemia as an evidence of the transformation of the mental world of the nobility and of its self-identification. Contrary to the previous research, the text presents a hypothesis shifting the acceptance of the chivalric cultural code to the beginning of the 12th century, thus to a significant extent erasing in this aspect the artificially created boundaries between the West European and the Central and East European regions in the medieval period.
\end{abstract}

Klíčová slova: středověká transformace - elita - rytířství

Key words: medieval transformation - elite - chivalry

DOI: $10.14712 / 25707213.2018 .3$

\section{Rytíríi, bojovníci, paradigma a „matrix minulého“"}

V poměrně košaté diskuzi o povaze českého středověkého státu za vlády přemyslovské dynastie, která se již téměř třináct let odehrává, lze nalézt, přes řadu rozdílných pohledů na vnitřní vývoj českých zemí v období 11.-13. století, přinejmenším jeden pevný bod. Je jím všemi přijímaný, či předpokládaný fakt, že na území přemyslovského regna probíhal v naznačeném období proces komplexní proměny vrcholící ve 13. století a dotýkající se kvalitativních i kvantitativních faktorů života společnosti. Jedním ze stěžejních aspektů dotčené problematiky budících v této souvislosti eminentní zájem badatelů zůstává otázka formování české středověké šlechty. Její zodpovězení je bytostně propojeno s řešením většiny sporných míst polemiky živené rozdílnými výklady povahy organizace veřejné moci $\mathrm{v}$ regnu přemyslovských knížat, jakož i disparátními pohledy na poměr mezi mocí panovníka a nobility. Dlužno připomenout, že kontroverze mezi pojetími se znásobují společně

1 Studie vznikla v rámci řešení projektu SGS15/FF/2016-2017 realita a skutečnost ve středověku, řešeného na FFOU. 
s historiografickou reflexí přerodu knížectví v království na počátku 13. století. Zde vedou k formulování odlišných hypotéz týkajících se samotného procesu proměny české raně středověké společnosti ve společnost, jejíž vnitřní struktura na počátku 14. století již v zásadě odpovídá - stejně jako relace mezi jejími členy - vrcholně středověkému „západoevropskému“ střihu (Třěstík - Žemlička 2007; Fan 2007; Žemlička 2007; Klápště 2011; Vaníček 2011). „Svoji“ diskuzi v tomto ohledu zažila ostatně přibližně ve stejné době i archeologie. I zde byla jedním ze základních problémů otázka spojené se šlechtou, konkrétně pak problematikou počátků šlechtických hradů (Klápště 2003; Durdík 2004; Razím 2004).

Lze vysledovat, že fenomén formování české šlechty zaujímá v rámci bádání zaměřeného na připomenutý proces společenské proměny dvojí roli. Na straně jedné je explicitně předmětem výzkumu. $\mathrm{V}$ této rovině se snažíme přinést odpovědi na otázku geneze a rané podoby české šlechty na základě popisu zapojení nobility 12 . století do politických, správních či hospodářských struktur přemyslovských Čech a Moravy. Vše má, jak už to bývá, i druhý, víceméně přehlížený, aspekt související s problematikou historiografické konstrukce historické „reality“, k níž docházelo řádově v horizontu posledních dvou století. V této rovině plní fenomén české šlechty (spolu s tím i její geneze a vývoje) roli jednoho z lakmusových papírků detekujících středověkou proměnu českých zemí jako takovou. Jednoduše řečeno, „ranost“ či „vrcholnost" forem života středověké společnosti v našich zeměpisných šírkách jsou posuzovány primárně na základě charakteristik, jimiž vystihují historičky a historici společenské elity daného období (tj. vedle panovníka též šlechtu). Rozdíl mezi „raným“ a „vrcholným“ proto mnohdy zůstává především rozdílem na úrovni charakteristik, kterými je v rámci modelových projekcí medievalistů přibližován svět elit. Takto vytvářená kategorizace středověké epochy je přitom v zásadě ahistorická, podléhající dichotomii „starý-nový“ (či „moderní“), jež je však nutně vlastní pohledu přes rameno, tj. $\mathrm{z}$ místa tady a ted' do minulosti, dichotomii, která nutně svádí k hodnotícím konotacím (Le Goff 2007, 40-67).

Pojetí „raného středověku“ vytvořené na české historické matérii přitom splývá s termíny: kníže, knížecí družina, hradská soustava, beneficium (ve smyslu výsluha), knížecí soud, atd., zatímco pojetí „vrcholného středověku“ se překrývá s termíny král, pozemková šlechta, královská komora, beneficium či feudum (ve smyslu léno), zemský soud atd. Spolu s tím nutí zmíněná kategorizace epochy k zavedení bodu předělu mezi „starým“ a „novým“. Jakkoli se dnes již historikové pod tlakem výsledků sociologických a kulturně-antropologických bádání odklonily od revolučně pojímaných cézur, a neuvažují o bodu, ale etapě či delším časovém horizontu společenské proměny, o dynamizaci české společnosti v časovém horizontu druhé poloviny 12 . až první poloviny 13 . století (Žemlička 1997, 265-309; Žemlička 2002, 197-544; Klápště 2005; Jan 2006, 172-253; Žemlička 2011, 37-83; Antonín 2012,68-182). Přesto zůstává motiv přelomu, jakožto nutná součást zvolené optiky, jedním z klíčových momentů celé diskuze o povaze české středověké státnosti. I to navrací motivy spojené s nobilitou, respektive šlechtou, stále znovu a znovu do hry.

Přehlédneme-li výsledky probíhající diskuze, je třeba uznat, že přinesla $\mathrm{v}$ řadě dílčích aspektů zpřesnění jak terminologického uchopení dané problematiky, tak prohloubení našich poznatků o fungování a vnitřních mechanizmech organizace středověké společnosti Čech a Moravy, jakkoli konec polemik není v této chvíli v dohledu. Uzavření diskuze o povaze české středověké státnosti v rámci všeobecného konsensu by snad za daného stavu bádání bylo předčasné a na škodu věci. V souvislosti s úvahami předloženými výše, je však třeba upozornit na skutečnost, že se naše bádání o elitách českého středověkého státu, jeho povaze a fungování, ocitá stále více ve virtuálním světě modelů založených na teoretických postulátech, které již v řadě případů nevznikají v procesu poznávání minulosti pomocí metod historické vědy, ale v důsledku sociálních interakcí, k nimž ve vědecké komunitě docházelo a dochází. Vědomá shoda mezi jejími příslušníky, jakož i shoda nevědomá, založená na apriorním přijímání hypotéz, které se tak stávají dále nedokazovanou, v zásadě mytologickou složkou poznávání minulosti, to obojí je tmelem převládajícího paradigmatu (Kuhn 1997; Feyerabend 2001; Antonín 2011).

Jistě, jde o jev, který provází historické bádání od nepaměti. Avšak vzhledem k roli, jíž se poznávání dějinný základů české státnosti i v dnešní době těší, jakož i váze, kterou doposud má historický argument v politických hrách 21. století, je třeba na dotčený virtuální aspekt procesu poznávání realizovaného moderní historiografí́ soustavně upozorňovat. Důvod je prostý. Vzhledem k etablování historie jako vědy, $\mathrm{k}$ němuž došlo $\mathrm{v}$ průběhu dvou předchozích staletí, získalo naše poznávání minulosti, realizované cechem odborníků vyzbrojených kritickou racionalitou a s ní úzce propojenými metodami, punc epistemologické operace vedoucí k (vědeckému) poznání jistých pravd, o které lze opírat nejen vědoucí reflexi př́tomného, jakož i rozhodnutí směřující do budoucnosti. Historické poznání, které si však nevytvář́ odstup samo od sebe, a tedy nereflektuje podmíněnost svých výpovědí motivací historiků jakožto jedinců, či skupin jedinců, rozhodujících se tady a ted' (a to nikoli nutně vždy na základě racionální a kritické úvahy), takové poznání se ocitá v poloze hada požírajícího svůj vlastní ocas. Stejně jako 
Uroboros se lačně vrhá na sebe samotné, považující svoje počáteční hypotézy vycházející primárně z kulturního a sociálního kontextu poznávajícího jedince za historickou skutečnost, z níž se stává nikoli teoretické východisko, které je třeba ověřovat, nýbrž „kriticky poznaná" dále nedokazovaná premisa - jakési místo paradigmatického uzlu, skutečnost, kterou každý ví a pokud ne, sluší se, aby věděl, či alespoň tušil.

Jistě nelze tvořit, a tedy ani bádat na poli dějin, bez momentu hermeneutického „předporozumění“ a s ním nutně spojené apriorní myšlenkové konstrukce vymezující nejen směr výzkumu, ale i jeho rozvržení a postup. Na tento hermeneutický kruh a jeho zákonitosti je však třeba soustavně upozorňovat, neztotožňovat interpretaci s faktem, neztotožňovat dějiny s „matrixem minulého“, virtuálním prostorem, v němž byl a je v konkrétním případě, jímž se chci na následných stranách zabývat, uzavřen i fenomén šíření rytířství v českých zemích. I ten, je dle mého soudu v současné české medievistice přirozeně propojen s problematikou vývoje české šlechty, a proto zkoumán $\mathrm{v}$ rámci diskurzivního pole politických a správně-hospodářských dějin, tedy oblasti, v níž je dnes z výše uvedených důvodů těžké odlišit virtuální svět stvořený historiografií a svět dějinných událostí a struktur per se. Těžištěm následujících úvah se proto stane tematizace „rytířství" v širším kontextu kulturního transferu probíhajícího v západní i střední Evropě v průběhu 11.-14. století, kontextu, v jehož rámci je civilizační proces možné chápat nejen bez ostrých cézur, ale i přechodových období, a spolu $\mathrm{s}$ tím i vnímat moment sociální proměny nikoli jako most vedoucí ze stavu A do stavu B, ale jako vlastní charakteristiku života společnosti, nalézající metaforické vyjádření již v pověstném Herakleitovském zlomku o říčním proudu.

\section{Historická věda na cestě za Svatým grálem}

Přes výše naznačený nejednotný pohled české medievalistiky na vývoj české státnosti 11.-14. století, panuje v zásadě všeobecná shoda na tom, že ke všeobecnému přijetí rytířství jakožto sociálního modelu v českých zemích dochází někdy od druhé třetiny 13. století. Důvodů, které vedou autorky $\mathrm{a}$ autory $\mathrm{k}$ těmto závěrům, je několik. Jedním $\mathrm{z}$ nich jsou sporé doklady o znalosti rytířských her - především turnajů - v pramenech české provenience před zmíněnou dobou (Jan 2005; Dvořáčková-MaláZelenka 2011, 209-221), druhým pak skutečnost, že o pronikání rytířské kultury uvažujeme v souvislosti se širrením ideálu rytíře v rámci epických a lyrických skladeb, které lokalizujeme až na dvoře Václava I. Mezi další argumenty náleží fakt archeologicky nedoložené výstavby hradů nového typu, k němuž se váže již ne tak zcela jasně prokazatelné „opoždění" procesu feudalizace české šlechty. Na rovnici feudalita = rytírství, kladené do souvislosti s absencí šlechtických hradů, turnajů a dvorského básnictví před rokem 1240, je založen výklad o pomalém (oproti říšskému prostředí) pronikání rytírství do českých zemí obecně, případně jeho úzké vazby na panovnické prostředí. Roli zprostředkovatele kulturního přenosu sehrává v těchto výkladech výhradně panovnický dvůr přemyslovských knížat a králů (Macek 1997; Soukup 2009; Dvořáčková-Malá - Zelenka 2011, 194-250).

Prezentovaný přístup se dle mého soudu vyznačuje několika slabinami. Jednou z nich je právě apriorní podřízení výzkumu rytířství paradigmatu převládajícímu v oblasti bádání o vývoji české středověké společnosti založenému na teorii tzv. středoevropského typu státu, v rámci něhož došlo ke zrodu české šlechty a feudalizaci společnosti až $\mathrm{v}$ průběhu 13. století - v rozsáhlejším měřítku spíše v jeho druhé polovině. Přitom platí, že diskuze o platnosti tohoto výzkumného rámce probíhá především na poli politických a hospodářských dějin a pro fenomén rytířství, zůstává paradigma platným, nebot' zpochybnění modelu předkládajícího hypotézu o nekompatibilitě světa české nobility 11. a 12. století se světem západoevropské šlechty téže doby, $\mathrm{k}$ němuž $\mathrm{v}$ rámci polemik došlo, nebylo doposud aplikováno ve $\mathrm{v}$ rámci výzkumu mentality nobility přemyslovského regna. Jakkoli i zde lze jmenovat výjimky sledující danou problematiku v širších strukturálních a kulturních souvislostech (Vaníček 2006; 2007), je patrné, že převládající tendence českého bádání zakládá své analýzy na interpretaci pramenů diplomatické a hospodářské povahy. Na rozdíl od západoevropské situace je však ve středo-východním evropském prostoru takto zacílené bádání odkázáno na několik málo kusů listin (v řadě případů mladších falz), dokládajících převážně posuny $\mathrm{v}$ rámci hospodářských struktur a implicitně zachycujících změny na úrovni státní organizace, formou jmenování typů úřadů etc. Tento prrístup navazující metodologicky především na tradici pozitivistického dějepisectví (s jeho důrazem na nalézání fakticity) a marxistické dějepisectví (zdůrazňující roli materiálních struktur ve vývoji společnosti) ztotožňuje realitu, jako celek, s fyzicky zažívanou zkušeností, což mu do značné míry znemožňuje sledovat problematiku života středověké společnosti právě na úrovni mentálních struktur.

Výsledky historického bádání dlouhodobě přijímajícího podněty z kulturně-antropologických a sociologických analýz ukazují, že naše vnímání toho, co je reálné, nutno rozšírit a zahrnout do tohoto „prostoru skutečného" i svět imaginace. Ten lze charakterizo- 
vat jako oblast vytvářenou jednak osobní, především však kolektivní zkušeností různých sociálních skupin a v posledku i lidstva jako druhu, tedy souborů zkušeností, jež jsou uchovávány v kolektivních pamětech lidských společenství a na obecnější úrovni též ve všeobecně sdílených kódech lidské kultury. (Assmann 2001; Halbwachs 2009).

Zmíněné imaginační oblasti, kladoucí horizonty myšlenkovým světům jednotlivců i společenství, ovlivňují jejich životy srovnatelnou měrou, jako svět fyzické existence. I proto je nutné považovat je za integrální součást reality (Le Goff 1998; Berger Luckmann 1999).

Přijetí tohoto metodologického východiska současně umožňuje změnu př́stupu $\mathrm{k}$ problematice geneze a vzniku české středověké šlechty. Našimi tématy již nebudou otázky zaměřené na rozsah majetku české nobility, forma jejího zapojení do správy regna a odměna $\mathrm{z}$ toho vyplývající, či hledání podstaty urozenosti. Na jejich místo nastoupí nové tázání spojené proměnami myšlenkového světa těch, kteří bojují, a především posunům na úrovni jejich sebeidentifikace. Stručně, pokusíme se sledovat proces kulturního přenosu na úrovni kolektivní identity a o ni se opírající identity jednotlivce. Jak se pokusím ukázat níže, tato změna optiky přesazuje výzkum šírení rytířské kultury v českých zemích do nového terénu, mimo výkladový rámec modelu středověkého typu státu, jakož i jeho kritiků. Opouští dosavadní apriorní svázání směru výzkumu s otázkami politického, hospodářského a správního vývoje. Posuny, k nimž došlo mezi 11.-14. v dotčených oblastech, vnímá v genetickém propojení s proměnami na úrovni mentálních struktur, bez snahy určit příčinu a důsledek. Vše zde tvoří metaforicky řečeno šroubovici DNA, tj. genetického kódu středověké kultury, neustále se proplétající ve spirálovitém procesu proměny. Kultura založená na tomto kódu, pak nikdy nenabývá podobu statického stádia, naopak, je věčným pohybem (Antonín 2012, 37-68).

Vrátíme-li se ještě na okamžik k současnému stavu bádání, pak za druhou slabinu výkladu kladoucího recepci sociálního modelu rytířství v českých zemích až k polovině 13 . století považuji skutečnost, že je jeho pronikání do našich zeměpisných šířek posuzováno až podle symptomů vrcholné rytírrské kultury, tedy především na základě výskytu dvorské epiky a lyriky, jakož i rytírských her na dvorech posledních Přemyslovců. Takto vedený výzkum přehlíží poznatky vztahující se k možnostem „hladkého“ kulturního transferu, které poukazují na nutnou dlouhodobou znalost přenášených vzorců jednání v prostředí prijímající kultury - v tomto konkrétním případě v prostředí české nobility, panovníka nevyjímaje pro jejich konečný úspěšný přenos. Stávající výklad počátku rytířství v Čechách však de facto operuje se zjednodušenou a poněkud schematickou představou přijetí celého sociálního konstruktu v již víceméně komplexní podobě - prostě tak, jak jej známe z básní Ulricha von Etzenbach či Wilhelma von Wenden (Iwańczak 2001, 19-49; Vaníček 2007, 178-188; Dvoř́ćcková-Malá - Zelenka 2011, 194-221).

Dotčený přístup tak sice zohledňuje kulturní odlišnosti, tradice, a tudíž i celkové možnosti přijímajícího prostředí absorbovat přenášené podněty, současně však přehlíží, že právě vzhledem $\mathrm{k}$ dotčeným možnostem transferu, je přijetí rytírství v českých zemích ve 13 . století v podobě vrcholné dvorské kultury, především dokladem skutečnosti, že k samotnému procesu poznání, přijetí a sdílení nových hodnot odpovídajících konceptu křestanského rytíře, docházelo v dlouhodobém horizontu po celé 12 . století, tedy od doby, kdy byl tento koncept přijat i v německé části Říše. Zdůrazněme však, že ani tehdy nešlo o přijímání komplexního kulturního vzorce jednání a očekávání, ale o recepci těch jeho aspektů, které byly českému prostředí blízké, nebo se mu postupně blízkými staly. K uchopení dané problematiky je třeba podstatně komplexnější rozbor, nevystačíme s „pouhou“ syntézou chronologických sousledností mezi prvními zmínkami o turnajích, hradech a rytířskou literaturou.

\section{Evropský kontext}

V prvé řadě nelze opomíjet evropský kontext vývoje rytíŕské ideje. Zde je třeba zdůraznit, že vývoj rytíŕství procházel i v geografických oblastech, které spojujeme s místem jeho zrodu, několika fázemi. Evropská historiografie přes řadu diskutabilních momentů chápe rytíŕství jako sociální konstrukt, který se uplatnil v souvislosti s dozráním společenských podmínek někdy mezi 9 . a 11. stoletím. Naznačená chronologie je současně jedním ze sporných míst a souvisí s otázkou, nakolik je miles 10 . století totožný s mužem vystupujícím v pramenech pod stejným označením na konci století jedenáctého. Od poloviny 11. století byl v souvislosti s tzv. bojem o investituru odstartován proces propojení ideálu světského válečníka s ideálem bojovníka za víru a Krista (miles Christi). Z pohledu evropské kultury se jednalo o synkrezi dvou prastarých ideálů: hrdinného válečníka (nejen) germánských ság a ideálu člověka vedoucího duchovní boj za křestanskou víru doprovázející církev od jejích počátků. V této souvislosti je „pravý“ středověký rytír identifikován právě až jako miles druhé poloviny 11. století opírajícího se i sociální status založený na úzkém propojení se sakrální sférou. Té se křestanský rytír přiblížil ještě více v souvislosti s argumentací ospravedlňující svaté války proti nevěřícím na samém konci 11 . století, kdy byly zahájeny 
křížové výpravy do Levanty. Přibližně v téže době vyjadřoval již termín miles také pocit sounáležitosti mezi skupinou lidí sdílejících určité hodnoty precizované církevními mysliteli (Harnack 1905; Wentzlaff-Eggebert 1960; Fleckenstein - Hellmann eds. 1980; Fleckenstein ed. 1985; Borst ed. 19892; Flori 2008).

Ve 12. století se již k obsahové náplni pojmu rytír vyjadřovala řada autorů, mimo jiné i John ze Salisbury, Bernard z Clairvaux a další. Shrneme-li jejich myšlenky, rytír 12 . století je bojovník vystupující jako opora církve, a proto též bojující s nevěřícími a ctící duchovní. Spolu s tím takový muž pečuje o chudé a udržuje mír, za což neváhá bojovat. Svou povinnost chránit přitom bere tak vážně, že je ochoten za ochranu chudých a míru položit život. Kodifikace rytírství jako systému vzorců jednání a očekávání opírajících se o výše popsané zásady byla následně rozvíjena v rámci nově vznikající dvorské kultury, kterou historiografie vnímá jako další ze sociálních konstruktů utvářejících se od sklonku 12. století. Na dvorech dochází k sebereflexi rytířského ideálu. Centrem, z něhož se tento proces rozšiřuje do všech koutů Evropy, byla Francie, avšak z obecné perspektivy vtiskla v období od konce 12 . do 14 . století rytířská kultura osobitý ráz celé středověké Evropě, středo-východní oblast kontinentu nevyjímaje. Přes lokální výlučnosti a modifikace tak středověký latinský svět propojila kultura, jejíž součástí je vše, co bývá s pojmem rytír v obecném povědomí dodnes spojováno: turnaje, koně, heraldické znaky, zbroj, válka, a v ní excitace cti, též lov a další dvorské zábavy; na dvorech pak nenaplněná láska, a tedy i ženy, potulní pěvci ... a mnoho dalšího (Bumke 19978; Iwańczak 2001; Fleckenstein 2002; Duby 2008; Flori 2008). Konec toho všeho je postupný, avšak ještě v 15. století, a mnohde i na počátku století šestnáctého, se rytířství jako komplex sociálních rolí těší nebývalému zájmu, jakkoli jde postupně spíše o rozmar, romantickou manýru, jež však představuje, podobně jako dnešní manýry, nesmírně důležitý komponent sociálního statusu nobility (Huizinga 1999, 103-225; Iwańczak 2004; Macek 1994). A vzhledem k českému prostředí ani to není vše, nebot' od konce 14. století je slova rytír užíváno i jako označení příslušníka stavu nižší šlechty - rytířského stavu (Macek 1996, 58-64). Rytírství tak nabývá nového významu. Tolik stručné chronologické shrnutí dané problematiky.

Za klíčový moment pro vývoj rytířské ideologie lze $\mathrm{v}$ rámci předestřeného přehledu považovat posun ve vnímání společenské vrstvy milites v průběhu 11. století, kdy získává rytířství prostřednictvím přijetí starého modu miles Christi sakrální aspekt, jenž je posílen na konci této epochy vyhlášením první kř́ižové výpravy. Rytířstvo se stává sociální skupinou, jejíž vymezení překonává majetkovou stratifikaci společnosti. Jde o společenství zahrnu- jící jak krále, tak drobného klienta sloužícího baronovi, jenž je královým leníkem. V téže době začíná vznikat teoretická představa o zásadách a formách rytírova života, tedy o ctnostech, které mají zdobit rytírovu osobnost a zrcadlit se $\mathrm{v}$ jeho jednání. V této vývojové fázi jsou v souvislosti s rytírským ideálem zdůrazněny především distinktivní ctnosti odkazující ke kardinální statečnosti, ale přesto, již tehdy doplňují morální profil ctnostného válečníka díla církevních autorit i o projevy participace na ctnostech křestanských: lásce, víře, naději. Nemylme se, doba dvorské kultury ještě zdaleka nenastala a rytíŕstvo je v rozmezí 11.-13. století, a v reálném životě i potom, společenstvím drsných chlapíků, cvičených od mládí v boji. Taktéž se nedomnívám, že tito muži v mládí studovali Salisburyho texty, aby věděli jak se chovat. Přesto se však ve zjednodušené podobě o „křestanských povinnostech“ své životní role dozvídali od duchovních, kteří pečovali o jejich duše. Rezonuje zde proces prohlubující se christianizace evropské společnosti, jejímž silným momentem v oblasti dotýkající se bojovnické ctnosti byl již několikrát zmíněný zrod křižácké ideje. Ta navíc napomohla univerzalizaci rytírské myšlenky, jež opustila Francii a v průběhu 12. století se ujala i v dalších koutech Evropy.

Právě tehdy, ve 12 . století, dochází ke stabilizaci evropské společnosti. Stabilizaci, jež byla vnitřně závislá do značné míry na morálce sdílené rytírstvem, morálce vratkých a mnohdy překračovaných zásad, přesto však rámcově kontrolující afekty pomocí excitace role cti nutící dodržovat morální principy. Rytírství se stává étosem. Na straně jedné jde o promyšlený krok ze strany církevní hierarchie, vedle toho je třeba společně s Norbertem Eliasem zdůraznit, že proces civilizace se ubírá i jinými směry než pouze reflexivní racionalizací světa vedoucí k postupné integraci společenské struktury. Dlouhodobé změny lidských individuálních i kolektivních struktur souvisí s upevňováním kontroly afektů, která nemá pouze racionální základ. Pojímat ustavení primárního modelu rytířství konce 11 . století pouze jako důsledek činnosti církve by znamenalo redukovat vývoj lidské kultury čistě na proces postupné racionalizace, spojené $\mathrm{v}$ tomto př́ípadě $\mathrm{s}$ prospěchem jedné instituce. Ustavení nového habitu však bylo mimo to založeno i na výše zdůrazněných iracionálních aspektech: pocitu studu a hanby za nedodržení slibu. Ovládání afektů kultivuje a vyžaduje sama společenská struktura nacházející se v tomto př́ípadě ve stádiu feudalizace, kdy je centrální moc, která by byla s to donutit lidi ke zdrženlivosti, oslabena. Přesto ve společnosti 11.-13. století narůstá potřeba potlačení fyzického násilí, či spíše jeho udržení v takových mezích, které neohrožují životnost společnosti jako takové. Součástí rytířství jako 
sociálního konstruktu je totiž v této době již obecně sdílená představa milosrdného zachování míru, řádu a spravedlnosti ve světě, propojená s ideálem panovnické moci, jenž je hoden následování. Překračování hranic dráždí svědomí a vyvolává hanbu a stud (Elias 2006, 266-278; Duby 2008, 307-322; Antonín 2013, 263-265).

Tato hypotéza pomáhá nalézt odpovědi na otázky, spojené s opětným obnovením moci králů ve druhé polovině 13. století - zasahujícím již nejen francouzské, či anglické, ale i české reálie. Opětný nástup panovnické moci, která nutí lidi žít podle zásad zemského míru, a jež přiměje lidi brát ohled i na jiné a afekty vybíjet mimo zemi, je umožněn právě tím, že si sociální skupina ovládající prostředky vedení války - šlechta - v průběhu 12. a 13. století opravdu hluboce osvojila kulturní kód nesený rytírrstvím. Výrazem naznačeného procesu osvojení je rozvoj dvorské kultury, činící i v českém království postupně od 13. století z drsné vojenské praxe hru, jejíž pomocí dochází ke kultivaci forem fyzického násilí - mimo jiné prostřednictvím rytířských turnajů a s nimi souvisejících her (Elias 2006; Barber-Barker 1991; Bumke 19978, 342-379; Macek 1997; Brzustowicz 2003; Jan 2005; Dvořáčková-Malá - Zelenka 2011, 209-221).

Na tomto místě lze tedy shrnout, že ve vývoji rytířské ideje je třeba v evropském kontextu rozlišit několik základních fází, jejichž datace je vzhledem k celé řadě aspektů čistě rámcová. V té první ukončené bojem o investituru, označoval termín miles bojovníka na koni, de facto elitního člena vojska. Od druhé poloviny 11 . do druhé poloviny 12 . století je již miles tím, koho dnes chápeme jako křestanského rytíře (válčícího ve „spravedlivé“ válce proti nevěřícím). Třinácté a první polovina 14. století pak přináší sebereflexi sociálního konstruktu rytířství projevující se zrodem a rozvojem kurtoazního rytířství a v návaznosti na to i rytířstvím představujícím zábavný prvek dvorské společnosti a její hodnotový systém zároveň. Čtvrtá fáze přichází s druhou polovinou 14. století a končí rámcově s přelomem 15 . a 16. století. Je charakteristická rytírskou reminiscencí a dvorskou manýrou mající však silný sociálně-stratifikační význam. Pro komplexní uchopení problému geneze a šíření rytířství v českých zemích by bylo zapotřebí sledovat, jakým zpo̊sobem se zde všechny řečené fáze projevovaly. V souladu s hlavním tématem předkládaného zamyšlení se však zaměřím pouze na pokus o zodpovězení otázky, kdy v českých zemích dochází k samotné proměně bojovníka v rytíře, jinými slovy, kdy česká šlechta přijímá kód křestanského rytíře spojený s druhou fází vývoje rytířského fenoménu. Odpověd' totiž může do značné míry lokalizovat moment proměny myšlenkového světa české elity.

\section{Země plná kostelů, země svatého Václava}

Prvním motivem, jenž sehrává v rámci sledované tématiky naprosto zásadní roli, se stane motiv v této době se šrurící vlny zakládání románských (emporových, vlastnických) kostelů. Česká medievalistika v tomto ohledu sledovala především právně-ekonomické dopady daného jevu, což dokresluje i několikerý výklad notoricky známé historky o bílinském kastelánu Mstišovi v podání kronikáře Kosmy (Cosmae Pragensis Chronica Boemorum, 111; Žemlička 1997, 201, 242; Klápště 2005, 48-52; Jan 2007, 893894; Klápště 2011, 62; Antonín 2012, 100-102; Velímský 2014, 337-347.)

Fenomén samotný však vedle toho nabízí přinejmenším dvě další interpretační roviny. $\mathrm{V}$ prvé řadě signalizuje změnu myšlenkového světa české nobility 12. století, jež odpovídá prohlubování christianizačního procesu ve středověkých Čechách v této době (Merhautová - Treštík 1984, 116; Berendová ed. 2013, 241-247). Čeští předáci plně přijímali křestanství jako „své“ náboženství a chopili se jej ve formě přístupné jejich mentálnímu horizontu. Víra pro ně představovala závazek, byla službou věčnému Králi králů - Ježíši Kristu. Vztah českých šlechticů ke Kristu tak získává podobu relace obecně spojované s feudální kulturou středověké Evropy (Merhautová 1971; Tomaszezoski 1974). Jednolodní kostely z českého, a v menší míře i moravského prostředí, jakož i klášterní šlechtická založení podle této interpretace dokládají postupné přijímání feudálních vzorců sociální stratifikace a s nimi i fenoménu rytířství tvořícího základní kulturní a komunikační kód mezi urozenými válečníky celé Evropy. S jejich světem se česká nobilita setkávala osobně v rámci četných válečných i mírových cest do všech koutů středověkého Západu. Jedná se o nesčetné pobyty předáků a knížat na císařském dvoře, jejich účast na třech křížových výpravách do Levanty, které se v této době uskutečnily, podíl na válečných taženích císařů do Itálie a dalších příležitostných výpravách (Žemlička 1997, passim; Žemlička 2006; Antonín 2012, 166-182). To nám umožňuje klást kontakt české nobility s rytířským ideálem a jeho přenos do českých zemí nejpozději do druhé poloviny 12 . století. Není jistě náhodou, že právě v této době nalézáme $\mathrm{v}$ pramenech případy užívání šlechtických predikátů, jakkoli jejich rozšíření spadá do 13. století (Žemlička 1997, 289; Klápště 2005, 88-92; Vaníček 2007, 171-175). I to přibližuje české šlechtice rytířskému světu západní Evropy.

Druhou interpretační rovinou, kterou nám vlna zakládání sakrálních jednolodních staveb nabízí vzhledem $\mathrm{k}$ výzkumu fenoménu rytířství, představuje hojně diskutovaná reprezentativní, a přede- 
vším fortifikační funkce těchto objektů, tvořících ve 12. století jeden z mála kamenných opěrných bodů v rámci tehdejšího stavitelského trendu ovlivňující charakter sídel české nobility. Lze shrnout, že výstavba kamenného kostela v sobě propojovala momenty křestanské víry a vizualizace výlučného postavení jeho zakladatele vůči zbytku společnosti s praktickými momenty válečnického řemesla, kdy se pevná a vysoká kostelní věž, jakož i sama kamenná budova kostela, stávala důležitým prvkem v rámci obrany šlechtických sídel (Merhautová 1971; Hejna 1977; Žemlička 1997, 288; Pauk 2001, 37-45; Klápště 2005, 52-99; Klápště 2011, 62-64; Laval 2016). Je zřejmé, že rozvoj výstavby takových fortifikačních areálů nutně souvisel s hospodářskými možnostmi nobility umocněnými rozvojem kolonizační aktivity, a že tedy nestačilo pouhé myšlenkové přijetí této formy sídla, ale i znalost technologie. Přesto však nelze podceňovat roli, kterou představovaly právě kamenné sakrální stavby 12 . století ve vývoji šlechtických sídel. Zdůrazněme, že jejich výstavba získává především ve druhé polovině nové umělecké impulsy přibližující „kamenný“ svět české nobility ke štaufskému ř́íšskému prostředí, které představovalo v této tobě symbiózu pestré směsice vlivů, mezi něž se řadila burgundská, lombardská, ale též alsaská stavební tradice (Mencl 1965, 38). Akcelerace stavebních aktivit tohoto typu je jedním z průvodních jevů kulturního transferu.

Př́́kladů, jimiž lze dotčený fenomén dokumentovat, není až tak málo, jak by se mohlo na první pohled zdát a jejich počet s každým dalším zpracováním archeologického materiálu narůstá. Do této množiny sakrálních staveb propojujících svět modlitby s obrannou funkcí lze ostatně zahrnout kupř́ikladu i známou rotundu z Týnce nad Sázavou, k níž byla okolo roku 1200 přistavěna masivní hranolová věž, s níž současně vznikal v těsné vazbě na areál i románský palác (Hejna 1977, 73-75; Glosová 1997). Symbióza posvátného a fortifikačního prostoru zde je natolik zřejmá, že byla tato rotunda zařazena jedním ze směrů českého archeologického bádání mezi tzv. hrady přechodného typu (Durdík 2006, 146-163). Jakkoli se tento typ a typologický přístup obecně netěší všeobecnému přijetí (Razím 2005), samotná situace, a to nejen ta u týnské rotundy, ale celková situace ve výstavbě románských kostelů, prozrazuje proměny mentality české nobility druhé poloviny 12. století, jejíž součástí bylo i přijetí kulturního kódu rytírství v podobě, kterou tento fenomén nabýval v západní Evropě po roce 1100. O této fázi jsme hovořili výše jako o předkurtoazní formě rytírské kultury.

Za všechny lze uvést př́klad, který je jedním z prvních dokladů nového trendu v českém sakrálním stavitelství, a současně se vzhledem k ostatním stav- bám tohoto typu (jednolodní kostel s vysokou věží) vymyká přítomností na svoji dobu a prostředí bohatého ikonografického programu. Samozřejmě jde o známou stavbu kostela sv. Jakuba v Jakubu u Kutné Hory vysvěceného podle historických pramenů biskupem Danielem roku 1265. O jeho zakladatelích, paní Marii se syny Slaviborem a Pavlem, nevíme mnoho (Merhautová 1971, 135-137; Merhautová Treštík 1984, 146-148, 175-175; Merhautová - Třeštík 1985, 74-76; Klápště 2005, 62-66). I v tomto případě jde o jednolodní stavbu opatřenou věží, představující obvyklý typ sakrální stavby druhé poloviny 12 . století. Jak již bylo řečeno, kostel sv. Jakuba je výjimečný svou reliéfní výzdobou tvořenou pískovcovými plastikami. Ty jsou umístěny ve slepých arkádách na jižním průčelí stavby a jejich interpretace není dodnes jednoznačně vyřešena. Součástí jižního průčelí je vstupní portál s reliéfním tympanonem, jenž zpodobňuje podle některých výkladů polofiguru Boha-otce, vystupujícího z oblak, oslavovaného dvěma anděly s kadidelnicemi a palmovými ratolestmi. Novější interpretace identifikuje dominantní postavu v tympanonu jako Krista. V arkádách po stranách portálu předpokládáme vyobrazení svatých Petra a Pavla. Interpretace horní řady reliéfů není taktéž zcela jistá. A. Merhautová a D. Třeštík předpokládali, že v arkádě nad portálem je zobrazen Kristus-vítězný, u jehož nohou klečí synové zakladatelky kostela Pavel a Slavibor. Před časem byla tato interpretace zpochybněna Pavlem Kroupou, který identifikoval postavu jako sv. Jakuba doprovázeného neznámými mladíky. V arkádě nalevo od nich je umístěna postava biskupa, napravo pak rytíŕe a opata. I při jejich identifikaci máme $\mathrm{k}$ dispozici dvě interpretace. Podle Třeštíka a Merhautové jde o sv. Vojtěcha, sv. Václava a sv. Prokopa (v době vzniku kostela však ještě nebyl kanonizován). Kroupův výklad ztotožňuje rytíre s postavou Rolanda, přičemž duchovní dále nespecifikuje (Merhautová - Treštík 1984, 177-178; Kroupa 1997, 10-21).

Za současného stavu bádání je nalezení stoprocentní jistoty v této otázce nemožné, domnívám se však, že pro naše téma, oscilující okolo myšlenkových horizontů českých urozenců 12. století, není samotná identifikace jednotlivých postav až tak podstatná. At již přijmeme jeden či druhý výklad, je zřejmé, že reliéfní výzdoba, vedle samotné schopnosti postavit a vybavit kostel a zajistit při jeho svěcení přítomnost panovníka, vypovídá o vysokém postavení a majetkových možnostech paní Marie a jejích synů. Obojí interpretace zobrazovaných postav navíc napovídá mnohé o myšlenkovém světě fundátorů. Odhaluje společenskou sebereflexi Marie a jejích synů, zařazujících se prostřednictvím středověké symboliky do společenstva křestanů - Boží obce (Merhautová Treštík 1985, 74-76). 
Pokud přijmeme výkladovou rovinu, podle které reliéfy znázorňují české světce, pak je u fundátorů kostela na místě uvažovat o pocitu sounáležitosti se společenstvím těch, které spojuje úcta k sv. Václavovi, Vojtěchovi a Prokopovi. Význam svatojakubského reliéfu by tak resonoval s texty kronik druhé poloviny 12. století, v nichž jsou Čechové identifikováni prostřednictvím vztahu k zemskému patronovi jako čeled' sv. Václava (Canonici Wissegradensis continuatio Cosmae, 203; Žemlička 1997, 336), věčného panovníka, který - a to je pro naše téma geneze rytířství v českých zemích podstatné - získává na stránkách narativních pramenů podobu do zbroje oděného rytíre, at' již pěšího či jedoucího na koni, avšak vždy vítězně zasahujícího do bitev tam, kde je Čechy neseno svatováclavské kopí. Otázkou symbolického významu reliéfní výzdoby kostela sv. Jakuba se dostáváme k dalšímu motivu umožňujícímu podchycení proměn mentality „Čechư “ dvanáctého století. Jedná se přirozeně o již mnohokráte v literatuře zachycenou proměnu svatého Václava ve středověkých Čechách (Merhautová - Třeštík 1985, 82-105; Žemlička 1997, 338-340; Antonín 2012, 89-92, 243-248).

Tento „rytírský aspekt“ podoby svatého Václava má svoje kořeny již v Kristiánově pojetí svatého knížete vítězícího nad kouřimským vévodou a je propojeno s motivem světce jako ochránce, jenž jako prostředník Boží vůle brání Čechy a jejich zemi (Kristiánova legenda, 100-102). Na několik míst v Kosmově kronice, kde k této reflexi svatého knížete dochází, bylo již v literatuře upozorněno (Cosmae Pragensis Chronica Boemorum, 2, 64, 154-155; Treštík 1968, 196200). Podobně je tomu i s příběhem světcova zásahu do pověstné bitvy u Chlumce roku 1126 zachyceným první generací Kosmových pokračovatelů, anonymními letopisci Kanovníkem vyšehradským a Mnichem sázavským. Zejména první ze jmenovaných důsledně zapojil do svého vyprávění přítomnost sv. Václava přímo na bojišti, kde se světec zjevil v bílém šatu a na bílém koni nad hrotem svatováclavského kopí, které držel kaplan Vít obklopen (podle kronikáře dle zvyku) stovkou českých předáků, proboštů a kaplanů. Jeho příchod byl přitom ohlášen orlem, kterého viděli bojovníci létat nad saskými šiky, zatímco Václava viděl pouze zmíněný kaplan. Spolu s tím uvedl příchod světce taktéž zvuk zvonu. Jakkoli zde sv. Václav nezasáhl do bitvy samotné a sehrával zde především roli svatého přímluvce u Boha, jenž svým zjevením přenesl milosrdenství Stvořitele na Čechy, popis jeho zjevení, v němž hrají důležitou roli atributy rytířského válečnictví - kopí a kůň, prozrazuje proměnu imaginace českých elit 12 . století (Canonici Wissegradensis continuatio Cosmae, 204; Monachi Sazawiensis continuatio Cosmae, 255; Graus 1975, 170-171; Graus 1977, 343).
Proměna vnímání věčného knížete Čechů tak především detekuje proces, který byl nastartován právě na počátku 12. století, a v dějinách evropského myšlení není ojedinělým úkazem - podobně roste v časovém horizontu 12.-13. století do podoby krále-rytíře i sv. Edmund v Anglii, sv. Olaf v Norsku či sv. Ladislav v Uhrách (Klaniczay 2002, 123-194) Tento proces představuje další $\mathrm{z}$ důkazů rozvoje rytířského ideálu v českých zemích v jeho dosud nezjemnělé, tj. „předkurtoazní“ podobě již před rokem 1200. Na straně jedné hraje při zobrazování svatého Václava, např́klad v rámci ikonografického programu denárových ražeb českých knížat, jakož i mincovních pečetí prvních českých králů, zdůrazňující především jeho roli věčného knížete. Ta je akcentována charakteristickým atributem svatého panovníka Čechů: kopím opatřeným praporcem (Čarek 1934, 4-9; Radoměřrsý - Ryneš 1958; Merhautová - Treštík 1985, 82-105; Nový 1988, 51-53; Berendová ed. 2013, 239-240). V této souvislosti je třeba zdůraznit, že zjevení se praporce sv. Václava není v první polovině 12. století v rámci evropského vývoje ničím nestandardním, naopak fenomén této svatováclavské relikvie symbolizující Bohem posvěcenou vládu má svoje analogie nejen v kulturně blízkých a propojených ř́íských oblastech, ale i ve francouzském království.

Vezmeme-li v potaz Rostislavem Novým naznačovanou chronologii procesu ustalování reverzního obrazu českých denárů, nelze si nepovšimnout, že se sv. Václav s kopím a praporcem do jejich ikonografického schématu dostává ve chvíli, kdy začínají i české kroniky připomínat, že Přemyslovci přijímají od římských králů své země v léno, právě prostřednictvím přijetí praporce přivěšeného na žerdi (tj. korouhve). Tento soulad lze chápat jako potvrzení významu praporce jako reálné insignie českých knížat. Pomyslné kořeny naznačeného kulturního transferu, v jehož centru stála symbolika kopí, je patrně třeba hledat jednak v činu císaře Jindřicha IV., jenž udělil českému knížeti Vratislavu II. právo nosit královské kopí ukořistěné českým panovníkem na Jindřichově protikráli Rudolfovi z Rheinfelden v bitvě u Flarchheimu (Ekkerhardi Uraugiensis chronica, 203; Dalewski 2000, 907-911; Malat'ák 2006, 53; Wihoda 2006, 78).

Pro vlastní upevnění místa symbolického významu kopí věčného knížete Čechů byla však též důležitá prozaická politika římskoněmeckých vládců vůči českým knížatům, jejímž charakteristickým rysem se po celé 12. století stalo udělování zemí jako léna. To od druhé půle tohoto věku dokonce předcházelo domácí volbě. Samotný akt investitury českých knížat se rozpadl do dvou fází. První představovalo přijetí léna, kdy se kníže stával panovníkem z moci císaře prostřednictvím „milosti praporce“, která, jak ukázal Zbigniew Dalewski, nebyla v evropském prostoru ničím neobvyklým, ba dokonce pronikla s nej- 
větší pravděpodobností do intronizačního rituálu polských knížat (Dalewski 1996, 124-127). V českém prostředí tak vlastně dochází k recepci této „ř́ršské zvyklosti“, která je v našich zeměpisných šírkách naplněna prostřednictvím svatováclavské ideologie svébytným myšlenkovým obsahem. Řádově od poloviny 12 . věku nepochybovali čeští analisté o tom, že toto kopí s sebou nosí Čechové do bitev, kde jej ještě ve 13 . století, např. roku 1260 v bitvě u Kressenbrunu (Př́běhy krále Přemysla Otakara II., 314-315) doprovází elitní oddíl těch, kteří bojují - milites, tj. rytírù.

V téže době (počátek 12. století) lze sledovat proces ustavení relikvie svatého kopí s praporcem mezi symbolickými předměty panovnické moci dodávající legitimitu vládě aktuálních panovníků též ve Francii. Přirozeně se jedná o Oriflamme, praporec opatství Saint-Denis namočený údajně do krve sv. Diviše, se kterým vyjel roku 1124 do bitvy proti římskému císaři Jindřichovi V. francouzský král Ludvík VI. a dobyl podle představ odrážejících se v dobových relacích zásluhou tohoto praporce rozhodujícího vítězství, čímž se význam svatého kopí ve francouzských dějinách zdaleka nevyčerpal (Schramm 1960, 139-141). Lze považovat za náhodu skutečnost, že pod podobnou standardou zasvěcenou taktéž domácímu dynastickému světci porazili Čechové o dva roky později ř́šské vojsko v již výše připomínané bitvě u Chlumce? Při odpovědi na tuto otázku si nevystačíme s konstatováním literární výpůjčky, ani se spojením přenosu znalosti motivu svatého kopí do českých pramenů s čistě intelektuálním prostředím mužů české církve, kteří se v rámci svých studijních pobytů v zahraničí seznamovali s tamním kulturním milieu (Merhautová - Třšstík 1983, 109-116; Antonín 2012, 121-122). Kopí s praporcem svatého Václava nepatřilo pouze do světa imaginace, bylo fyzicky existujícím předmětem se symbolickou funkcí. Domnívám se, že právě jeho př́klad dokládá skutečnost postupné unifikace základních souřadnic kulturního kontextu, který přes rozdílnou aplikaci danou lokální tradicí (jinou formu nabývá na jeho základě formovaná sociální realita ve Francii, Anglii, říši či v českých zemích), propojoval mentální horizonty evropské šlechty. Proměna svatováclavské ideologie spojená nejen se světcovým kopím, ale jeho rolí svatého ochránce a věčného panovníka obecně, v tomto ohledu ukazuje, že zmíněná kontextualizace se nevyhnula ani světu české nobility.

A jak to vše souvisí s recepcí předkurtoazních forem rytířství v českých zemích? Odpověd' je prostá. Zásadně, nebot rytířský ideál byl nedílnou součástí kultury, z níž se zrodil fenomén svatých a věčných panovníků-ochránců a jejich svatých předmětů, mimo jiné i kopí. Význam svatováclavské ideologie tak, jak o něm pro 12 . století česká historiografie již mnoho let uvažuje, by byl bez současného při- jetí rytířských ideálů šírících se v téže době značně marginalizován. To, že česká nobilita však již tehdy sedlala rytírské koně, vysvítá nejen z narativních pramenů, k nimž se záhy dostaneme, ale i z již připomínaných denárů. I na nich lze vedle roviny zdůrazňující symbolický význam kopí lze již ve 12. století sledovat linii svatováclavské ikonografie akcentující rytírsskou podobu věčného knížete. Poprvé jej můžeme doložit jedním z typů ražeb Bořivoje II., kde je sv. Václav zobrazen jako na koni cválající rytír ve zbroji, v některých případech se štítem a kopím (Cach 1972, č. 314-317; Merhautová - Treštík 1985, 89-90). Jezdecký motiv se následně, jakkoli ne v převažující míře, objevuje i na averzních stranách českých denárů 12. století, např́íklad na ražbách Vladislava I. s explicitním zachycením rytíre probodávajícího kopím nepřítele (Cach 1972, č. 534-537) a dalších (Cach 1972, č. 557, 561, 568, 574, 583, 596, 598, $607,646,655,658,666)$. Ve 13 . století se v souladu s dobovou módou postupně prosadil motiv rytířského jezdce i na panovnických pečetích (Kuthan 2007, 153-206). Stejně tak jsou již ze 12. století známa i zpodobnění věčného knížete Čechů zachycujícího jej jako stojícího rytíře s mečem či žezlem v ruce. Za pomyslný vrchol tohoto typu svatováclavské ikonografie v přemyslovských Čechách lze snad považovat její využití na pečeti Starého Města Pražského užívané nejpozději v 80. letech 13. století.

Motiv stojícího rytíre s mečem a štítem, kterýje taktéž propojen se svatováclavským reversem, jakož i aversem přemyslovských denárů (Cach 1972, č. 461-465, 479, 485, 494, 497, 539, 544, 547, 546, 620, 629, 640) nás přivádí zpět k reliéfní výzdobě kostela sv. Jakuba. V této souvislosti je třeba zdo̊raznit, že ani druhá výkladová rovina identifikující svatojakubského rytíře jako Rolanda není z pohledu našeho tématu bezvýznamná. Ba naopak. Její platnost by potvrzovala prŕibuznost myšlenkového světa české a evropské nobility 12 . století, jež se stržena proudem rytířské kultury, přenášela do mechanismů celospolečenské evropské proměny snad ještě více, než ztotožnění této postavy se sv. Václavem. V tomto ohledu nelze totiž přehlížet, že jeden z projevů změny, které lze $\mathrm{v}$ rovině mentality sledovat, představuje rostoucí popularita poutnictví na svatá místa, mezi něž náleželo i Santiago de Compostela s ostatky sv. Jakuba. To vše přitom úzce souviselo se stupňujícím se bojem proti nevěŕícím, který se neodehrával pouze ve Svaté zemi, ale i na Pyrenejském poloostrově. Jedním z prvních rytírů reconquisty byl právě legendární křestanský rytíř Roland, jehož život sloužil jako vzor pro tehdejší šlechtu. Propojení reliéfní výzdoby kostela sv. Jakuba s těmito „pyrenejskými“ motivy, by tak de facto vytvářelo argument o poměrně vyspělé myšlenkové absorpci ideje svaté války ve světě české nobility 12. století, a propojila by jej nejen s křižác- 
kou, ale především se svatým bojem úzce související rytířskou ideou.

\section{Ztraceni v překladu?}

O tom, že české intelektuální prostředí vnímalo podněty rytíŕské kultury již ve 12 . století, stejně jako prostředí říšské, svědčí řada dokladů, které přinášejí narativní prameny z této doby, Kosmovou kronikou počínaje. $\mathrm{V}$ řadě př́ípadů však zůstávají historikům skryty. Př́ćinou je způsob, jímž je v moderních překladech nakládáno s termíny Kosmova slovníku, v našem konkrétním př́ípadě pak s pojmem miles. Ten je v českých edicích pramenů pocházejících z období před rokem 1200 překládán v souladu s významem, jenž měl v klasické latině jako „bojovník“ a Kosmova kronika v tomto není výjimkou. Současně však v překladech pramenů z přelomu 12. a 13. století, popř́ipadě přímo ze třináctého století, se již překladatelé nebojí užít jako český ekvivalent slova miles termín „rytíř́. Obojí překlad tak odpovídá kontextu současného stavu historického bádání, podle kterého prostě rytíri ve 12 . století v českých zemích neexistovali, jelikož k tomu nedozrály hospodářské a společenské podmínky. Opět se zde ocitáme v „matrixu minulého", opět narážíme na jeden z důsledků přijetí modelu středověkého středoevropského státu. Dotčený překlad totiž podvazuje naše současné uvažování, v němž nenabývá pojem bojovník zdaleka tak široké eticko-mravní konotace jako termín rytír, jenž sám o sobě odkazuje k existenci společenstva sdílejícího společný hodnotový systém, jak jsme o tom mluvili výše. Když však opustíme tuto optiku a přijmeme jako východisko naopak hypotézu, podle které lze šíření rytířství v jeho „předkurtoazní“ fázi v českých zemích zasadit již do 12 . století, můžeme na tehdejší vývoj pohlížet způsobem, v němž se začne řada jednotlivých aspektů společenské proměny, na které literatura doposud upozornila, skládat do komplexního obrazu, jehož výsledná podoba se blíží k situaci na území středověké římské říše.

Již v Kosmově kronice lze nalézt pasáže svědčící o tom, že pražskému děkanovi nebyl svět rytírské válečné cti a slávy cizí. Ukazuje to například jeho kritika pozdějšího pražského biskupa Jaromíra, jenž zpočátku odmítal přijmout duchovní dráhu a přijav rytírský pás (cingulum militare) uprchl k polskému knížeti (Cosmae Pragensis Chronica Boemorum, 110-111). Podobně připomíná verbování rytírư (milites), patrně ministeriálů, řezenského biskupa Vratislavem II., jenž vyjížděl do boje proti markraběti Východní marky Leopoldovi. Stejně jako oni jsou označeni i vítězní moravští a čeští válečníci - na pole přitáhli Vratislavovi bratři Ota a Konrád se všemi, kteří byli na Moravě militibus. Je zřejmé, že Kosmas klade důraz na fakt, že vojsko Čechů a Moravanů bylo pečlivě vybíráno, jeli ti, které středověk zná jako bojovníky na koních (tj. rytíŕe). Oproti tomu Kosmas zdůrazňuje, že markrabí přikázal táhnout do boje všem, kdo mohli, od pasáka sviní po pasáka volů. Když se setkala obě vojska v bitevním poli, nechává Kosmas pronést Leopolda řeč ke svým lidem, kteří jsou i v tomto př́padě osloveni jako milites. Ti jsou podle kronikáře uspořádáni na způsob dřevěného klínu, tedy v bitevním rozestavení, kdy jsou na hrotu a po obvodu formace umístěni ti nejlepší a obrnění bojovníci, bránící méně oděné válečníky uvnitř formace. Leopold se tedy ve své promluvě obrací právě k těmto elitním bojovníkům na špici, kteří však patrně pro zachování jednoty voje nastupují do boje pěší. Lze to dedukovat nejen $\mathrm{z}$ většinové skladby vojska z Východní marky, ale i z toho, že ve chvíli, kdy se s ním má Vratislav utkat, přikáže svým mužům sesednout z koní a postavit se Rakušanům v pěším boji (Cosmae Pragensis Chronica Boemorum, 131-132). Je zřejmé, že jde v první řadě o výpůjčku z letopisu Reginona z Prümu, který stejným způsobem líčí vstup krále Arnulfa do jedné z četných bitev, které vybojoval (Reginonis abbatis Prumiensis Chronicon, 137-138). Dost možná souvisí tento motiv se snahou o archaický ráz vyprávění. Současně však lze v souvislosti s předchozí charakteristikou vojska markraběte Východní marky též uvažovat o tom, že Kosmas nechtěl nechat zvítězit Čechy na koních v nerovném boji proti nedostatečně ozbrojeným sedlákům, o nichž dříve hovoř́i. At tak či onak, zdá se, že se na tomto místě v pojetí pražského děkana odráží dobová proměna válečníka a způsobu vedení boje. Kosmas odlišuje elitní bojovníky na koních, kteří, jakkoli jsou v početní menšině, přemáhají většinu boje neznalých mužů markraběte stejně, jako lvíčata stádo ovcí. Tyto milites však již dle mého soudu není třeba nazývat bojovníky, ale rytíři, kteří jako výše zmiňovaný bratr knížete Jaromír přijali život ve znamení rytírského opasku.

Na tom, že si Kosmas jednak velice dobře uvědomoval rozdíly mezi různými typy válečníků a současně užíval pro souhrnné označení české nobility termín milites, není nic nového. Byl to on, kdo tuto vrstvu vnitřně stratifikoval tím, že ji rozdělil na milites primi et secundi ordinis - tj. jízdní bojovníky prvního a druhého řádu, jednoduše rytíre více a méně urozené. V této souvislosti si neodpustím ještě jeden př́klad. Vztahuje se k roku 1087 a jde o známý př́íběh, ve kterém vybral král Vratislav dva šiky mužů a poslal je se svým synem Břetislavem do vesnice Kyleb v Míšeňsku, aby zde pomstili smrt několika českých urozenců. Břetislav vše provedl, vracel se s kořistí, avšak na zpáteční cestě jej při koupeli v řece překvapil oddíl Sasů. Jakkoli se je podařilo mladému knížeti porazit, zaplatila za jeho nerozváž- 
nost životem řada z předních Čechů, kteří se výpravy účastnili. Povšimněme si několika detailů. Podle Kosmy vysílá Vratislav se synem duas scaras ex electis militibus (dva šiky z vybraných bovníků/rytíruo ). Současně k nim však náleželi i tzv. scutarii - štítonoši, které v téže souvislosti jmenuje jako milites secundi ordinis, tj. bojovníky/rytíře druhého řádu. Tuto složku vojska, náležící mezi výše uvedené dva šiky, vyslal Břetislav napřed s kořistí. Břetislava a nobiles (urozené), kteří s ním zůstali u řeky, přijel do léčky vylákat oddíl dvaceti aequites (tj. lehce oděných jezdců), za nimiž se Čechové vrhli. Ze zálohy je však překvapili jiní Sasové - „odění do železa“ (ferrea legio Saxonum). Čechové, kteř́i setrvali v táboře u řeky, se následně chopili zbraní a vyrazili na pomoc nerozvážným a chabě vyzbrojeným druhům. Jak proběhl následný střet? Kosmas je zde více než výmluvný. První souboj byl střetem na kopí, ta se lámou a nastupuje boj meči - hastila in primo congressu franguntur, res gladiis agitur. Za imaginaci českého autora počátku 12. století by se nemusel stydět žádný z autorů rytířských skladeb 13. století. I proto lze vyslovit názor, že Kosmovy milites můžeme nazývat rytíři (Cosmae Pragensis Chronica Boemorum, 141-143). Pak je však otázkou, zda se v souladu se západoevropským bádáním nelze domnívat, že faktická vnitřní stratifikace uvnitř sociální skupiny těch, kteří bojují, nutně předpokládá vytvoření vzájemných vazeb a vztahů mezi nimi navzájem, jakož i panovníkem, vazeb, které lze chápat jako adaptaci feudálních vztahů, jež se ve 12. století šírí na celém říšském území (Reynolds 1994, 440-451; Wihoda 2007).

Pokud lze pochybovat o naznačeném výkladu fenoménu rytířství v Kosmově kronice, domnívám se, že naprosto zřetelnou podobu nabývají formy rytířského života $\mathrm{v}$ díle biskupského kaplana Vincencia, jenž s pomocí literární symbolické zkratky miles-rex přibližuje svému publiku postavu druhého českého krále Vladislava II. Jde o charakteristiku provázející krále od počáteční věty, kdy jej Vincencius charakterizuje nejen pomocí obecné formule o slávě, jasnosti a vznešenosti krále, ale i zdůrazněním jeho soustavných vítězství (Vincentii canonici Pragensis Annales, 407). Svou odvahu a bojové nadání projevil Vincenciův Vladislav II. již v bitvě u Vysoké, kde se utkal s vojskem moravského údělníka Konráda. Mnozí z českých předáků však Vladislava zradili přesně ve chvíli, kdy již bitva začínala. Namísto toho, aby kníže a jeho bratři bojující po jeho boku, jakož i olomoucký biskup Zdík uprchli z bojiště, vrhli se - Vladislav jako první - prŕmo doprostřed nepřátelských šiků a probili si cestu do Prahy (Vincentii canonici Pragensis Annales, 412).

Vliv rytíŕského ideálu na popis Vladislava se projevil patrně nejvýrazněji v souvislosti s jeho podílem na tažení Fridricha I. Barbarossy do Itálie a zde pak v bojích u Milána. Byl to český vládce, který se neohroženě jako první vrhl do vod řeky Addy poté, co se dvěma z jeho rytírú podařilo objevit místo, kde bylo možné její tok přebrodit, a svou př́kladnou odvahou strhnul ostatní Čechy. Byl to on, kdo v čele českých šiků vyráží na pomoc císařovu bratru Ludvíkovi, jenž se dostal při obléhání Milána do těžkého postavení. Ve svém skvostném odění pak osobně probodl kopím milánského korouhevníka Decia. Všude kolem něj se pohybovali Čechové - rytířsky bojující a umírající. Ve vzpomínkách na tyto události bude o několik let později charakterizovat jejich činy ve světě českých kronik především srdnatost a bojovnost - základní vlastnosti každého správného křestanského rytíre. (Vincentii canonici Pragensis Annales, 430, 436-437). Př́kladi̊ z Vincenciova díla by se dalo citovat více. Souhrnně lze říci, že letopisec a přímý účastník popisovaných válečných událostí přistupuje k identifikaci české šlechty prostřednictvím rytírských ctností i k vylíčení krále Vladislava pomocí rytířského ideálu, jemuž jak on, tak jeho současníci v českých zemích rozuměli.

V souvislosti s geopolitickým začleněním českého knížectví nejde o nic mimořádného. Úzké sepětí Čech a Čechů s říšským prostorem vytvářelo přirozený most, po němž docházelo k šírení kulturních vzorců po celá staletí. Rytírství a jeho ideální podoba nepředstavovaly v tomto ohledu výjimku. Ve druhé polovině 12 . století dochází k rozšriření a obecnému přijetí nového bojovnického étosu na dvoře Vladislavova současníka, císaře Fridricha I. Barbarossy, kde se pohyboval poměrně často nejen druhý český král, ale i česká šlechta a duchovenstvo. Recepci rytířského ideálu v rámci ideologie moci odráží typologie ctností, které s Fridrichem I. spojují historiografové a další literáti jeho doby. Mezi nimi dominuje statečnost, a s ní spojený úspěch na válečném poli (Krieg 2003, 115-138). Naprosto zásadní roli přitom hraje moment císařova prvenství v boji. Kronikáři staví svého hrdinu vždy o kousek před samotné vojsko, do čela, odkud svou odvahou a válečnickým umem strhne celou armádu. Tyto relace zrcadlí požadavek na panovníkovu osobní účast v čele rytírrských šiků, jenž byl vưči osobám vládců vznášen v souvislosti s rozvojem rytířství a přijetím jeho ideálu a současně souvisel s fenoménem spravedlivé války, jehož myšlenkové schéma se formovalo v průběhu 11. století a jasné obrysy získalo v době prvních kruciát do Levanty. Panovníkovo místo na čele šiku souviselo s jeho obecným posláním sloužit Bohu prostřednictvím naplňování zásad míru, spravedlnosti, řádu a milosrdenství. Jeho statečnost a osobní nasazení přináší vítězství, které tak získává aspekt zjevené Boží vůle. Bitva se stává ordálem legitimity panovníkovy moci (Russell 1975). Okamžik, ve kterém bude panovník zproštěn této povinnosti, aniž by utrpěla 
jeho čest, je v tuto chvíli ještě daleko. Přichází až na přelomu 13. a 14. století v souvislosti s nástupem nadosobních idejí, jako byly patria a corona, spojujících společnost na principech vzdalujících se původnímu germánskému válečnému štěstí krále, jež bylo křestanskou věroukou zjemněno a modifikováno v souladu s jeho etickým myšlením (Kantorowicz 1957, 259-268; Hellman ed. 1961).

Ve 12. století však panovník ovládá muže meče, na jejichž loajalitě v mnohém závisí prosperita a úspěch jeho vlády, stále jako první rytír, jehož statečnost zrcadlí v náboženských představách tehdejších válečníků Boží milost, jež činí z krále toho, kým je. Charakterové rysy a motivy jednání postav Vladislava II. a Fridricha I. jsou v kronikářských relacích modelovány přesně podle výše uvedené charakteristiky ideálu rytířského krále, oplývajícího statečností a štěstím v boji. Domnívám se, že tato představa nebyla omezena pouze na svět literárních děl. Naopak, jednalo se o ideu všeobecně sdílenou těmi, kteří panovníka obklopovali a spoluvytvářeli svým jednáním podmínky pro vizualizaci jeho majestátu. Pokud platí závěry, ke kterým došlo předchozí bádání (Antonín 2013, 260-265), a tento majestát byl, a to i v českém prostředí ve 12 . století propojen s rytířským ideálem, je na místě domnívat se, že se s řečeným ideálem identifikovali právě i ti, kteří krále denně obklopovali, bavili se, válčili po jeho boku a jeho jménem spravovali zemi. Jednoduše, milites českých pramenů byli v tomto kontextu již rytíri, sociální skupinou, jejíž členové vyznávali hodnoty, které válečnický étos obohatily po střetu o investituru a v souvislosti s rozvojem fenoménu kř́žových výprav do Svaté země. Ostatně i těch se, jak jsme již zdůraznili výše, Čechové účastnily.

\section{Reminiscence tak řečeného Dalimila namísto závěru}

Teprve výše popsaný kulturní kontext životů českých urozenců tvořící se v průběhu 12. století byl předpokladem pro další krok, jímž bylo přijetí kurtoazní podoby rytírsství. Rozhodující roli zde sehrálo umění, které se od druhé poloviny 12 . století v oblasti západní Evropy a v první polovině 13. století v Evropě střední zmocnilo motivu rytírského hrdinství. Jeho prostřednictvím pronikl ideál do samotné struktury vztahů mezi jednajícími osobami a následně i do systému očekávání a usilování společenské vrstvy, pro kterou byla umělecká díla primárně určena. Rytířská epika a lyrika, jakož i život na dvoře se staly prostředky procesu civilizace. Jejich přijetí a rozvoj kultivuje afekty všech, kteří na ně přistoupí - šlechty, ale i krále. Tato literární díla nejen že se stávají studnicí jasných př́íkladů, s jejichž pomocí je jako v př́ípadě knížecích zrcadel, dále tř́iben panovnický ideál (jakož i ideál rytířský). Troufám si říci, že literatura a její prríběhy pronikaly do myšlenkového světa středověké elity patrně hlouběji než normativní návody předpisující panovníkovi (jakož i rytíri) způsoby adekvátního jednání a reakcí na hypotetické podněty. Ztotožnění se s hrdiny imponujícími svými schopnostmi a činy a nápodoba jejich jednání měnily svět představ členů středověké nobility. Umění zde snad vůbec poprvé v evropských dějinách, rozkládá mentální prostředí napříč společenskou strukturou, aby je v další fázi složilo do podoby snažící se přiblížit rytířské fikci, která, jak jsme viděli výše, měla svůj základ v kulturním archetypu ideálního panovníka. Tento krok je v mnohém zásadní, nebot' na něj navazuje přerod kultury středověkého Západu jako takové. Sít očekávání a představ je na řadě míst proměněna (Slanař 2006; 2009).

Je jistě pravda, že zrod dvorského typu rytíre spadá v našich zeměpisných šířkách do období posledních Přemyslovců a souvisí primárně s rozvojem německého a teprve od počátku 14. století též českého básnictví. Na toto téma bylo již napsáno mnohé a domnívám se, že není třeba fenomén minnesängrů na dvorech Václava I., Přemysla Otakara II. a Václava II., jakož i problematiku české Alexandreidy, dále rozvádět. Připomeňme však, že přes částečné inovace a aktualizace $\mathrm{v}$ tomto žánru běžných motivů a prríběhů prostřednictvím „českých“ reálií nejde o autochtonní umění, ale doklad plného přijetí kulturních vzorců, které jsme sledovali výše. Rozvoj uvedených literárních žánrů tak není pouze počátkem kurtoazních forem života české šlechty, ale z našeho pohledu především přirozeným vyústěním postupné proměny myšlenkového světa české šlechty, která od 12 . století prijímala rytířskou ideu, a ve druhé polovině 13. století dospěla do bodu sebereflexe prostřednictvím jejího uměleckého ztvárnění. Tento vývoj je možná opožděný vzhledem k francouzským reáliím, nikoli však k reáliím středoevropským, a tedy i ř́šským. Autoři tvorrící ve staročeském jazyce se chápou vyprávění v závislosti na latinských a německých textech. Písemná fixace přitom nemusí zdaleka odpovídat rozvoji tématu formou ústní tradice. Přichází spíše po ní. Současně dotčené příběhy přetrvávají i v době, kdy již nejsou vzhledem k reálné politické praxi vlastně aktuální. Stávají se výrazem manýry, jejíž sdílení však zakládá identitu nobility stejně, jako její majetek a urozenost (Behr 1989; BokPokorný 1998; Iwańczak 2001; Vaníček 2007, 178-188; Žurek 2009; Dvoŕácková-Malá - Zelenka 2011).

$\mathrm{V}$ souvislosti s významem, který jsme přisoudili rozvoji fenoménu rytířství v rámci vývoje české šlechty ve 12 . století, není bez zajímavosti reflexe, kterou této době věnuje tak řečený Dalimil, jenž kladl původ řady významných šlechtických rodů a jejich 
erbovních znamení právě do souvislosti s hrdinnými činy, jichž se jejich „praotcové“ dopouštěli vesměs ve 12. století. A když hovoříme o Dalimilovi, nelze opomenout, že moderní rozbory myšlenkového světa anonymního, staročesky veršujícího autora zdůrazňují mnohdy jeho kritiku rytířské kultury oproti starým dobrým časům (Bláhová 1995, 230-232; Iwańczak 2001, 145-147). Jaké však byly tyto staré časy, kdy se Čechové, jak tvrdí Dalimil, sice neproháněli na turnajovém kolbišti, ale zato měli více válečného umu než muži z kronikářovy doby? Odpověd' je prostá. Staročeskému kronikáři splývá tato doba s 12. stoletím, kdy se Čechové zapojovali v jeho pojetí do bojů po boku jednotek římskoněmeckých panovníků v Itálii. Již dřívější rozbor jeho kroniky zaměřený na př́klady kronikářovy narativní strategie při charakteristice českých panovníků ukázal, že Dalimilovi nebyla myšlenka rytířského života zdaleka cizí (Antonín 2013, 231-247).

Domnívám se, že jeho ideálem byl miles dvanáctého a první poloviny třináctého století. Ten byl již i v českém prostředí rytířem, jenž však provozoval své rytířství v době, kdy v českých zemích dosud nedošlo k sebereflexi společenské role těch, kteří bojují formou literárního klišé, době předcházející zjemnění rytířského vzorce jednání a jeho posunutí do role dvorské zábavy. Dalimil tak vlastně nekritizuje rytírství jako takové, ale jeho dvorskou zjemnělou podobu zavánějící spíše hrou a avantýrou, která se autorovi zdá, oproti „vážným“ činům vážných předků směšná (Staročeská kronika tak řečeného Dalimila II, 327). Reminiscence staročeského kronikáře tak podtrhuje významy, jež pro šíření rytířské ideje v českých zemích sehrály společenské procesy odehrávající se ve 12. století, které se odrážejí v posunech mentálních horizontů nobility, tak jak jsme je sledovali výše. Jejich součástí byla dle mého soudu i proměna sebeidentifikace českých bojovníků, ztotožňujících se s ideálem křestanského rytíře zrozeného v procesu následujícím po boji o investituru. Tuto identitu přijímala česká nobilita dle výše představené interpretace již v době, kdy vznikala Kosmova kronika - už zde vystupující milites sedlali rytírské koně. Tuto hypotézu bude přirozeně třeba ještě podrobit důkladnému prověření. Pakliže by se však ukázala jako oprávněná, je třeba klást si otázku, co tento oproti dosavadním názorům „urychlenýc transfer kulturních kódů a znalostí vypovídá o diskutovaných společensko-právních a hospodářských aspektech vývoje české šlechty, a zde pak především o interpretaci vývoje české státnosti v období 11.-14. století.

\section{Prameny}

Canonici Wissegradensis continuatio Cosmae, FRB II., ed. Josef Emler, Praha 1874, 201-237.
Cosmae Pragensis Chronica Boemorum, MGH SRG NS 2., ed. B. Bretholz unter Mitarbeit von W. Weinberger, Berlin 1923.

Ekkerhardi Uraugiensis chronica. MGH SS 6., ed. G. H. Pertz. Hannoverae 1844.

Kristiánova legenda. Ed. Jaroslav Ludvíkovský, Praha 1978. Př́běhy krále Přemysla Otakara II., FRB II., ed. Josef Emler, Praha 1874, 308-335.

Reginonis abbatis Prumiensis Chronicon cum continuatione Treverensi, Scriptores rerum Germanicarum in usum scholarum separatim editi 50, Monumenta Germaniae Historica, hrsg. Friedrich Kurze, Hannover 1890.

Staročeská kronika tak řečeného Dalimila I.-II., edd. J. Daňhelka - K. Hádek - B. Havránek - N. Kvítková. Praha 1988. III. Marie Bláhová: Historický komentář, rejstř́k. Praha 1995.

Vincentii canonici Pragensis Annales. FRB 2., ed. J. Emler, Praha 1874, 407-460.

\section{Literatura}

Antonín, R. 2011: Model středoevropského typu středověkého státu jako interpretační problém české a polské medievistiky. Historia Slavorum Occidentis. Czasopismo historyczne/Časopis historický 1, 65-76.

Antonín, R. 2012: České země za posledních Přemyslovců I. díl (1192-1253). Cestou proměny společnosti $\mathrm{k}$ vrcholně středověké monarchii. Praha.

Antonín, R. 2013: Ideální panovník českého středověku. Kulturně-historická skica $\mathrm{z}$ dějin středověkého myšlení. Praha.

Assmann, f. 2001: Kultura a pamět. Písmo, vzpomínka a politická identita $\mathrm{v}$ rozvinutých kulturách starověku. Praha.

Barber, R. - Barker, F. 1991: Die Geschichte des Turniers. Düsseldorf - Zürich.

Behr, H.-F. 1998: Literatur als Machtlegitimation. Studien zur Funktion der deutschsprachigen Dichtung am böhmischen Königshof im 13. Jahrhundert. München.

Berendová, $\mathcal{N}$. (ed.) 2013: Christianizace a utváření křestanské monarchie. Skandinávie, střední Evropa a Rus v období 10.-12. století. Praha.

Berger, P. I. - Luckmann, T. 1999: Sociální konstrukce reality. Pojednání o sociologii vědění. Brno.

Bláhová, M. 1995: Staročeská kronika tak řečeného Dalimila (III.) v kontextu středověké historiografie latinského kulturního o kruhu a její pramenná hodnota. Historický komentár. Rejstř́ík. Praha.

Bok, V. - Pokorný, f. (eds.) 1998: Moravo, Čechy, radujte se! Němečtí a rakouští básnící v českých zemích za posledních Přemyslovců. Litteraria germano-austro-bohemica 1. Praha.

Borst, A. 19892: Das Rittertum im Mittelalter. Wege der Forschung 349. Darmstadt.

Brzustowicz, B. W. 2003: Turniej rycerski w królestwie polskim w późnym średniowieczu i renesansie na tle europejskim. Warszawa.

Bumke, f. 19978: Höfische Kultur. Literatur und Gesellschaft im hohen Mittelalter. München. Fleckenstein, J. 2002: Ritterturm und ritterliche Welt. Berlin.

Cach, F. 1972: České a moravské denáry od mincovní reformy Břetislava I. do doby brakteátové. Praha.

Čarek, f. 1934: O pečetech českých knížat a králů z rodu Přemyslova. Praha.

Daleweski, Z. 1996: Włada, przestrzeń, ceremoniał. Miejsce i uroczystość inauguracji władcy w Polsce średniowiecznej do końca XIV w. Warszawa. 
Daleweski, Z. 2000: Die Heilige Lanze und polnische Insignien. In: Europas Mitte um 1000. Beiträge zur Geschichte, Kunst und Archäologie 2. Stuttgart, 907-911.

Duby, G. 2008: Tři řády aneb Představy feudalismu. Praha.

Durdík, T. 2004: K počátkům šlechtických hradů v Čechách, Archeologické rozhledy 56/1, 169-175.

Dvoř́ćková-Malá, D. - Zelenka, 7. 2011: Curia ducis, curia regis. Panovnický dvůr za vlády Přemyslovců, Praha.

Elias, N. 2006: O procesu civilizace. Sociogenetické a psychogenetické studie. I. Proměny chování světských horních vrstev na Západě. Praha.

Feyerabedn, P. K. 2001: Rozprava proti metodě. Praha.

Flori, 7. 2008: Rytíri a rytířství ve středověku. Praha.

Fleckenstein, f. - Hellmann, M. (eds.) 1980: Die geistlichen Ritterorden Europas. Vorträge und Forschungen 26. Sigmaringen.

Fleckenstein, F. (ed.) 1985: Das ritterliche Turnier im Mittelalter. Beiträge zu einer vergleichenden Formen- und Verhaltensgeschichte des Rittertums. Veröffentlichungen des Max-Planck-Instituts für Geschichte, Bd. 80. Göttingen.

Glosová, M. 1997: Příspěvek k poznání rotundy hradu v Týnci nad Sázavou na základě oprav interiéru, Památky středních Čech. Zpravodaj Památkového ústavu středních Čech v Praze 11/1, 31-37.

Graus, F. 1975: Lebendige Vergangenheit. Überlieferung im Mittelalter und in den Vorstellungen vom Mittealalter. Köln - Wien.

Graus, F. 1977: Der Heilige als Schlachtenhelfer - zur Nationalisierung einer Wundererzählung in der mittelalterlichen Chronistik. In: K.-U. Jäschke - R. Wenskus (eds.): Festschrift für Helmut Beumann zum 65. Geburtstag, Sigmaringen, 330-348.

Halbwachs, M. 2009: Kolektivní pamět', kritické vydání připravené Gérardem Namerem za spol. Marie Jaissonové. Praha.

Harnack, A. 1904: Militia Christi. Die christliche Religion und der Soldatenstand in den ersten drei Jahrhunderten. Tübingen.

Hejna, A. 1977: Opevněná venkovská sídla doby přemyslovské v Čechách. Výsledky archeologického výzkumu z období 1965-1975. Archeologia historica 2, 69-79.

Hellmann, M. (ed.) 1961: Corona regni. Studien über die Krone als Symbol des Staates im späteren Mittelalter. Darmstadt.

Huizinga, f. 1999: Podzim středověku. Jinočany.

Iwańczak, W. 2001: Po stopách rytířských příběhů. Praha.

Iwańczak, W. 2004: Husitské války a etika doznívajícího rytírství. In: M. Drda - M. Vybíral (eds.): Jan Žižka z Trocnova a husitské vojenství v evropských dějinách. VI. mezinárodní husitologické sympozium Tábor 12.-14. ř́ina 200, Husitský Tábor - Supplementum 3. Tábor, 183-194.

Fan, L. 2005: Počátky turnajů v českých zemích a jejich rozkvět v době Václava II. Listy Filologické 2005, 1-19.

Jan, L. 2006: Václav II. a struktury panovnické moci. Brno.

Jan, L. 2007: Skrytý půvab „středoevropského modelu“. Český časopis historický 105, 873-902.

Kantorowicz, E. H. 1957: The King's Two Bodies. A Study in Mediaeval Political Theology. Princeton.

Klaniczay, G. 2002: Holy Rulers and Blassed Princesses. Dynastic Cults in Medieval Central Europe. Cambridge.

Klápště, f. 2003: Poznámky o sociálních souvislostech počátků šlechtických hradů v českých zemích. Archeologické rozhledy 55/4,786-800.
Klápště, f. 2005: Proměna českých zemí ve středověku. Praha.

Klápště, f. 2011: O rané šlechtě v českých zemích. Malý náčrt velkého tématu. In: Co můj kostel dnes má, nemůže kníže odníti. Věnováno Petru Sommerovi k životnímu jubileu. Praha, 61-66.

Krieg, H. 2003: Herrscherdarstelung in der Stauferzeit. Friedrich Barbarossa im Spiegel seiner Urkunden und der staufischen Geschichtsschreibung. Vorträge und Forschungen 50. Sigmaringen.

Kroupa, P. 1997: Průzkum jižního průčelí lodi kostela sv. Jakuba v Jakubu u Kutné Hory. Průzkumy památek 4/1,3-26.

Kuhn, T. 1997: Struktura vědeckých revolucí. Praha.

Kuthan, f. 2007: Splendor et Gloria Regni Bohemiae. Umělecké dílo jako projev vladařské reprezentace a symbol státní identity. Praha.

Laval, F. 2016: Co je kostel? K počátkům šlechtických sídel českého středověku. Archeologické rozhledy LXVIII, 47-90.

Le Goff, f. 1998: Středověká imaginace, Praha 1998.

Le Goff, F. 2007: Pamět' a dějiny. Praha.

Macek, f. 1994: Jagellonský věk v českých zemích 1471-1526, 2. Šlechta. Praha.

Macek, 7. 1997: Česká středověká šlechta. Praha.

Malaták, D. 2006: Korunovace přemyslovských králů. In: Stát, státnost a rituály přemyslovského věku. Problémy, názory, otázky, Sborník př́spěvků z konference konané dne 18. října 2005 v Brně, 47-66.

Mencl, V. 1965: Panské tribuny v naší románské architektuře. Umění 13, 29-62.

Merhautová, A. - Třšstík, D. 1983: Románské umění v Čechách a na Moravě. Praha.

Merhautová, A. - Treštík, D. 1985: Ideové proudy v českém umění 12. století. Praha.

Merhautová, A. 1971: Raně středověká architektura v Čechách.

Norý, $R$. 1988: Symboly české státnosti v 10.-12. století, FHB 12, 47-63.

Radoměrský, P. - Ryneš, V. 1958: Společná úcta sv. Václava a Vojtěcha zvláště na českých mincích a její historický význam. Numismatické listy 13, 35-48.

Razím, V. 2004: Nad počátky hradů české šlechty. Archeologické rozhledy $56,176-214$.

Razím, V. 2005: O tzv. hradech přechodného typu. Archeologické rozhledy 57, 351-380.

Reynolds, S. 1994: Fiefs and Vassals. The Medieval Evidence Reinterpreted, Oxford.

Russell, H. F. 1975: Just War in the Middle Ages, Cambridge studies in Medieval Life and Thought, ser. III, vol. 8. Cambridge.

Schramm, P. E. 19602: Der König von Frankreich. Das Wesen der Monarchie vom 9. zum 16. Jahrhundert. Ein Kapitel aus der Geschichte des abendländischen Staates I.-II. Weimar.

Slanař, O. 2006: K otázce topiky ve středověké rytířské epice. In: D. Dvořáčková-Malá - J. Zelenka (ed.): Dvory a rezidence ve středověku I. Mediaevalia Historica Bohemica - Supplementum 1, Praha, 273-286.

Slanař, O. 2009: Zábavné funkce v rytířské epice českého stř̌edověku. Na př́kladu eposu Tandariáš a Floribella. In: D. Dvořáčková-Malá - J. Zelenka (ed.): Všední a sváteční život na středověkých dvorech. Dvory a rezidence ve středověku III. Mediaevalia Historica Bohemica Supplementum 3, Praha, 533-543. 
Tomaszerwski, A. 1974: Romańskie kościoły z emporami zachodnimi na obszarze Polski, Czech i Węgier. Wrocłav - Warszawa - Kraków - Gdańsk.

Trěstík, D. 1968: Kosmova kronika. Studie k počátkům českého politického myšlení. Praha.

Treštík, D. - Žemlička, J. 2007: O modelech vývoje přemyslovského státu. Český časopis historický 105, 122-163.

Vaníček, V. 2003: Strukturální vývoj sociálních elit v českých zemích do roku 1310 (základní vývojové tendence, metodologické souvislosti). In: Genealogia - stan i perspektywy badań, Toruń, 233-300.

Vaníček, V. 2006: Spiritualizace étosu šlechty: miles Christianus, militia Dei (K strukturální typologii raných elit). In: Světci a jejich kult ve středověku. Praha, 83-107.

Vaníček, V. 2007: Sociální mentalita české šlechty: urozenost, rytírství, reprezentace (Obecné souvislosti, pojetí družiny, „modernizační" trend. In: Šlechta, moc a reprezentace ve středověku. Colloquia mediaevalia Pragensia 9, Praha, 141-188.

Vaníček, V. 2011: Středověká modernizace jako koncept strukturální promèny pro středovýchodní Evropu. In: Dynamika przemian społecznych i religijnych w średniowieczu. III. Kongres Mediewistów Polskich (2008), Warszawa, 11-37.

Velímský, T. 2014: Vzestupy a pády bílinských hradských správců. In: Středověká Evropa v pohybu. K poctě Jana Klápště. Praha, 325-363.

Wentzlaff-Eggebert, F.-W. 1960: Kreuzzugsdichtung des Mittelalters. Studien zu ihrer geschichtlichen und dichterischen Wirklichkeit. Berlin.

Wihoda, M. 2006: První česká království. In: Stát, státnost a rituály přemyslovského věku. Problémy, názory, otázky. Sborník př́spěvků z konference konané dne 18. října 2005 v Brně, k vydání připravil Martin Wihoda ve spolupráci s Demeterem Malatákem, Brno, 67-99.

Wihoda, M. 2007: Kníže a Jeho věrní. Kosmas o světě předáků a urozených. In: M. Nodl - M. Wihoda (eds.): Šlechta, moc a reprezentace ve středověku. Colloquia mediaevalia Pragensia 9, Praha, 11-29.

Žemlička, J. 2006: Wallfahrten aus Böhmen nach dem Heiligen Land und ihre kulturelle Bedeutung bis Mitte des 12. Jahrhunderts. In: D. Doležal - H. Kühne (eds.): Wallfahrten in der europäischen Kultur. Frankfurt am Main, 37-52.

Žemlička, J. 2009: O „svobodné soukromosti“" pozemkového vlastnictví. K rozsahu a kvalitě velmožské pozemkové držby v přemyslovských Čechách. Český časopis historický 107, 269-308.

žurek, V. 2009: Mittelhochdeutsche Dichtung in Böhmen der Přemysliden. In: M. Brauger - P. Rychterová M. Wihoda (eds.): Die mittelalterliche Kolonisation. Vergleichende Untersuchungen. Studentische Arbeiten aus dem internationalen Seminar, veranstaltet in Prag, vom 7. bis 11. März 2005, Praha, 167-194.

\section{From a warrior to a knight - incidental remarks on the transformation of the Czech lands in the High Middle Ages}

In the initial passages of the study, the author returns to the discussion concerning the character of the Bohemian medieval state during the reign the Prremyslids. In this context, he deals with the issue of the formation of Bohemian medieval nobility. Subsequently, the author presents the conclusions reached by the existing literature concerning the phenomenon of the spreading of chivalry in the Bohe- mian milieu, commenting critically on the methodological starting point which puts the beginnings of the spreading of chivalry in the Czech lands as late as towards the middle of the 13th century. In contrast to that, the author attempts to open a new path to gaining knowledge of the Bohemian elites of the 11-13th centuries. He does not ask questions concerning the extent of the property of the Bohemian nobles, the form of their involvement in the administration of the regnum or the rewards for it, or the substance of nobility. Instead, his questions concern self-identification of the Bohemian nobility, following the process of cultural transfer on the level of the collective identity and, based on it, of the identity of an individual. On this level, he puts the development of the chivalric idea into pan-European context, distinguishing several basic phases in it and subsequently focusing on answering the question of when the code of the chivalric knight was accepted by the Bohemian nobility in the Czech lands. He interconnects the process of adoption of this code with a wave of foundation of Romanesque (matroneum) churches in the 11-12th centuries, which signals a change of the mental world of the Bohemian nobility. Aisleless churches from the Bohemian - and to a less extent also the Moravian - milieu evidence the gradual acceptance of the feudal patterns of social stratification and, along with them, of chivalry. The study also presents the opinion that the construction of a stone church interconnected within itself the aspects of the visualisation of the founder's exclusive position towards the rest of society with practical aspects of the art of war, as the firm and high church tower as well as the stone church building itself become important defensive elements of noble residences. The acceleration of this type of construction activities is one of the phenomena accompanying the cultural transfer.

The text points out that it is signalled also by the gradual transformation of St Wenceslas, who becomes described in the pages of the narrative sources as an armour-clad knight intervening in battles, always victoriously, where the Bohemians bear the lance of St Wenceslas. The transformation of the perception of the eternal duke of the Bohemians thus detects a process that started precisely at the beginning of the 12th century. It is not a unique phenomenon in the history of European thought - St Edmund in England, St Olaf of Norway of St Ladislaus in Hungary similarly grew into the form of king-knight during the 12-13th centuries. This represents another proof of the development of the chivalric ideal in the Czech lands in its unsoftened, "pre-courteous" form already before 1200 . The author follows this phenomenon further, documenting it also on the development of St Wenceslas iconography. He finds further arguments within the analysis and interpretation of the narrative sources and the use of the term miles in them. On this level, the study points out the often misleading and tendentious way of translation of this term into Czech, which corresponds above all to the context of modern historical research and does not respect the discourse of the medieval texts themselves. In the Czech editions of the sources from the period before 1200 , the term miles is translated as "warrior" (bojovník), in accordance with its meaning in classical Latin; at the same time, however, the translators of the sources from the late 12th and early 13th centuries no longer fear to use the term "knight" (rytír) as the Czech equivalent of the word miles. Both translations thus correspond to the context of the present state of historical research, according to which knights simply did not exist in the Czech lands in the 12th century, because the economic and social conditions had not matured for 
their existence. The author comes to the conclusion that there are passages in Cosmas' chronicle demonstrating that the world of chivalric war honour and fame was not alien already to the dean of Prague. According to his argumentation, the forms of the chivalric life gain a clear shape in the world of the episcopal chaplain Vincentius. The analysis is concluded with an example of reminiscence of the Old Czech chronicler, the so-called Dalimil. The author presents the hypothesis that Dalimil's ideal was the miles of the 12th and the first half of the 13th centuries. In this context, Dalimil's reflection underlines the importance of the spreading of the chivalric idea within the framework of the transformation of Bohemian society in the 12th century, when the mental horizons of the nobility were changing and its members were identifying themselves with the ideal of a Christian knight.

\section{Robert Antonín}

Katedra historie Filozofická fakulta, Ostravská univerzita v Ostravě

Reální 5

70103 Ostrava

email:robert.antonin@osu.cz 